\title{
A STUDY OF THE TYPHOID COLON INTERMEDIATE GROUP OF BACILLI, WITH SPECIAL REFERENCE TO COMPLEMENT-FIXATION REACTIONS.*
}

\author{
JoHN A. KOLMER, W. WhITRIDGE WILLIAMS \\ AND \\ ANNA M. RAIZISS.
}

(From the Laboratories of Experimental Parhology, University of Pennsylvania, and Philadelphia Polyclinic, Philadelphia, Pennsylvania.)

One of the most difficult problems in bacteriology is the study, classification, and differentiation of members of a "group" of closely allied organisms. Thus individual members may differ from each other in pathogenicity but possess such similar morphological characteristics as to require most careful biological and cultural study for differentiation. Frequent and persistent efforts have been made in attempts to transform types and while the secondary and non-essential features may be changed temporarily, such as dimensions, motility, growth upon ordinary culture media, etc., the cardinal and vital characteristics remain on the whole unchanged. For purposes of study and classification a prominent member is selected as the characteristic organism of the group and the remaining members grouped under that head. Owing partly to the fact that the various organisms of a "group" are found living in the same portions of the body as the diphtheria group in the upper air passages, the colon-typhoid group in the intestinal tract, etc., it is widely accepted that the various members of a group may have been derived from an original species, but owing to longcontinued variations in environment have adopted slight but fairly well-defined cultural and biological characteristics which are transmitted from generation to generation. This theory of "mutation" has much in its support as relates to bacteria differing but slightly from the parent, but as regards the relationship between the more prominent members of a group it is hardly tenable. Thus much work has been reported upon the relation of $B$. coli to $B$. $t y$ phosus and the possibility that $B$. typhosus may have been derived

* Received for publication July I6, rgr3. 
originally from $B$. coli by a loss of certain zymogenic and the acquisition of pathogenic properties, but the possibility of this change is not proven by experimental investigation, notwithstanding various reports concerning changes in cardinal characteristics, as $B$. coli losing its power of producing indol and coagulating milk or $B$. typhosus producing indol upon prolonged cultivation.

Most reliance in the differentiation of members of a group of closely allied organisms is placed upon their fermentative action upon carbohydrate media, agglutination reactions, and tests for pathogenicity and virulence. Since the discovery by Bordet and Gengou of the specific relationship of antigen and antibody as determined by complement-fixation experiments, this method of investigation has been applied to the study of "groups" of organisms based upon the assumption of strict specificity of antigen for its immune amboceptor. Thus Besredka, ${ }^{1}$ Foix and Mallein, ${ }^{2}$ Swift and $\mathrm{Thro}^{3}$ have reported that immune bodies specific for different strains of streptococci can be demonstrated by means of the complement-fixation test. Kolmer ${ }^{4}$ working with five strains of streptococci, with the specific purpose of studying the relationship of the streptococcus commonly found associated with scarlet fever to the group of streptococci, found that differentiation among these was possible when using high dilutions of the immune sera but in lower dilutions differentiation was not found by means of comple. ment-fixation tests, the results indicating either that this scarletfever streptococcus belonged to the common group of streptococci or that the complement-fixation test was but a group reaction. In a similar study applied to the diphtheria group of bacilli with the purpose of studying the relationship of Hofmann's bacillus or the pseudo-diphtheria bacillus to the true virulent Klebs-Loeffler organism, Kolmer ${ }^{5}$ found analogous results, namely, that the pseudo-diphtheria bacillus could not be differentiated from other members of the group by complement-fixation reactions, indicating that this bacillus was probably derived originally from the parent of the group and has been gradually so changed by environment as to

I Ann. de l'Inst. Pasteur, 1904, 28, p. 363.

2 Presse med., r907, I5, p. 777 .

4 Ibid. I912, 9, p. 220.

${ }^{3}$ Arch. Int. Med., I9I I, 7, p. 24.

s Jour. Infect. Dis., 1912, 11, p. 44. 
adopt certain cultural and transmissible characteristics, thus constituting another example of "mutation" among bacteria.

In this communication is reported a similar study applied to the typhoid-colon group of bacilli. While it is comparatively easy to differentiate the typhoid from the colon bacillus, there is an intermediate group between the two which partakes of the morphological, cultural, and pathogenic properties of both, rendering their practical differentiation extremely difficult. The bacilli of this "intermediate group" have attracted attention chiefly in connection with meat poisoning, protracted fevers clinically indistinguishable from mild typhoid infections, and in certain acute intestinal infections of the lower animals. Attempts to study the interrelationship of various members and systematize their grouping have been made by Buxton, Durham, Kutscher and Meinickle, and many others with special reference to cultural characteristics; fermentative action upon carbohydrate media, and agglutination reactions with immune sera, and the latter two methods of study probably remain the best means of differentiation.

In a general way the object of this study was to further investigate the specificity of complement-fixation reactions in the differentiation of bacteria of a group. Since members of a group bear such a close cultural and morphological relationship to each other, it must be expected that the antibodies, as agglutinins and amboceptors, would not be absolutely specific for their antigen or if the amboceptor were specific it would demonstrate this specificity only with an antigenic substance not common to the group. In such a study, therefore, the question of preparation of antigen becomes quite important.

Thus the purpose of the investigation was:

(r) To make a further study of complement-fixation reactions in the differentiation of bacteria belonging to a general "group."

(2) To determine more specifically if such reactions would demonstrate the relationship of the members of the typhoid-colon group of bacilli to each other and serve as a means of differentiation among them.

(3) To compare the efficiency of complement-fixation reactions 


\section{J. A. Kolmer, W. W. Williams, and A. M. Raiziss}

with acid and gas production tests and agglutination reactions in differentiating among the members of the group.

METHOD OF STUDY.

This consisted in the careful selection from a number of cultures of 44 strains of bacilli belonging to the typhoid-colon group.' These were studied for gas and acid production with various sugars in litmus and neutral red broth; for indol production, coagulation of milk, etc. Rabbits were immunized and the sera used for agglutination and complement-fixation experiments.

1. Cultures.-The following cultures were selected for the study from a large, number at our disposal:

\begin{tabular}{|c|c|c|}
\hline No. & Organisms & \\
\hline $\mathbf{r}$ & B. coli communior & \\
\hline 2 & B. coli communis & Coli group \\
\hline 3 & B. lactis aërogenes & \multirow{8}{*}{ Enteritidis group } \\
\hline 4 & B. enteritidis & \\
\hline 5 & B. paracoli & \\
\hline 6 & B. hog cholera & \\
\hline 7 & B. fecalis alcaligenes & \\
\hline 8 & B. paratyphosus A & \\
\hline 9 & B. paratyphosus A & \\
\hline ro & B. paratyphosus B & \\
\hline I I & B. dysenterica (Flexner) & \multirow{4}{*}{ Typhosus group } \\
\hline 12 & B. typhosus, Strain A & \\
\hline $\mathbf{I} 3$ & B. typhosus, Strain B & \\
\hline 14 & B. cholera & \\
\hline
\end{tabular}

Each culture has been given a number and the immune serum and "antigen" of a culture is designated according to the number in recording the agglutination and complement-fixation experiments. Thus No. I refers to culture of $B$. coli communior, its immune serum, antigen, etc.

The cultures have been divided into groups according to Park, except that $B$. dysenterica is placed in the typhosus group. This arrangement is based upon the principal or cardinal characteristics of closely allied species and has proven of much aid in a study of the entire group.

a) Coli group.-Dextrose and lactose fermented with gas formation; milk coagulated with acid production; motility sluggish; indol produced by most varieties.

b) Enteritidis group.-Dextrose fermented with gas formation;

:We wish to express our thanks to Dr. K. F. Meyer, Dr. D. Rivas, Dr. John Reichel, and the Museum of Natural Fistory, New York, for many cultures kindly given us. 
lactose not fermented; milk not coagulated; no indol or only slight amounts produced; motility usually marked ( $B$. alcaligenes ferments no sugars).

c) Typhosus group.-Dextrose fermented without gas production; lactose not fermented; milk not coagulated; no indol except with certain types of $B$. dysenterica; milk not coagulated; $B$, dysenterica non-motile.

While $B$. cholera does not belong to the group of typhoid-colon bacilli, it was included in this study as a control.

Our aim was to select representative cultures as different cultures of the same species will show minor variations. Thus all cultures of $B$. coli possess major characteristics, as acid and gas productions with glucose, indol formation, coagulation of milk, etc., but cultures possessing these cardinal characters will differ from each other in their action with other sugars, as saccharose, raffinose, and mannite. In the face of this variability of $B$. coli it is to be expected that minor variations occur with different cultures of B.typhosus, not to mention the possible variations among the intermediates. Fermentation reactions are usually chosen as the means of classification, because of the comparative ease with which the organisms may be differentiated from those of other groups and because of the facility with which each variety may be separated from the others. The characteristics of the cultures used in this study are given in Table $\mathbf{I}$.

The differentiation between $B$. coli communior and $B$. coli communis is based upon the investigations of Durham, the former producing gas with saccharose as well as with dextrose and lactose, the latter only with dextrose and lactose. According to the work of Jackson ${ }^{1}$ the culture of $B$. coli communior belongs to type A and $B$. coli communis to type $\mathrm{B}$.

It will be noted that with trypsinized broth $\left(\mathrm{Rivas}^{2}\right)$, indol could be demonstrated in 24 hours with the cultures of B. coli. A parallel series were conducted with peptone (Witte) water and tested after 12 days' incubation. The results were similar with the exception of $B$. lactis aërogenes which produced indol in peptone water but not within 24 hours in the trypsinized broth. In using the latter

I Jour. Amer. Pub. Healih Assoc., 191 1, 1, p. 930.

¿Centralbl. f. Bakterial., 1 Orig., I912, 63, p. 547. 
medium care must be taken not to carry the process of digestion too far and controls should be used for the same reason as testing for indol with peptone water. With these precautions the trypsinized broth gives excellent results.

All cultures were tested with the various sugars for acid production or reduction of neutral red broth. With this medium the presence of acid may be shown in two different ways: $(a)$ the neutral red broth becomes dark purple in color or $(b)$ the broth is decolorized or of a yellowish color. In both instances the changes are due to the presence of acid but just why the different colors are

\begin{tabular}{|c|c|c|c|c|c|c|c|c|c|c|c|c|c|c|c|c|c|c|c|}
\hline \multirow[b]{2}{*}{ No. } & \multirow[b]{2}{*}{ ORGANISM } & \multicolumn{2}{|c|}{ INDOL } & \multirow[b]{2}{*}{$\stackrel{\mathrm{E}}{\mathrm{Z}}$} & \multirow{2}{*}{ 总 } & \multirow{2}{*}{ 兽 } & \multirow{2}{*}{ 暻 } & \multicolumn{12}{|c|}{ Sugars } \\
\hline & & $\begin{array}{c}\text { Tryp- } \\
\text { sin- } \\
\text { ized } \\
\text { Broth } \\
24 \text { hrs. }\end{array}$ & $\begin{array}{l}\text { Pep- } \\
\text { tone } \\
\text { I2 } \\
\text { days }\end{array}$ & & & & & 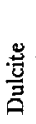 & 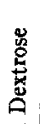 & 嵌 & 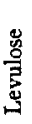 & 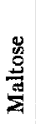 & 萼 & 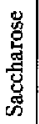 & 嵌 & 点 & 思 & 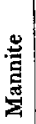 & 宸 \\
\hline I & B. coli communior. . & + & + & + & - & + & + & + & + & + & + & + & $\rightarrow$ & + & + & $x$ & + & + & + \\
\hline$\frac{1}{2}$ & B. coli communis..... & + & t & + & - & + & \pm & + & + & $x$ & + & + & + & $\stackrel{T}{x}$ & $x$ & $\hat{x}$ & + & + & $\dot{x}$ \\
\hline 3 & B. lactis aërogenes. . . . . . & - & + & + & - & + & - & $x$ & + & + & + & + & + & + & + & $x$ & + & + & $\hat{+}$ \\
\hline 4 & B. enteritidis.......... & - & - & $\dot{x}$ & - & - & + & + & + & $\dot{t}$ & + & + & -1 & - & - & - & $\dot{x}$ & + & + \\
\hline 5 & B. paracoli. . . . . . . . & - & - & - & - & - & + & + & + & $\dot{t}$ & + & + & $\times$ & - & - & $x$ & $x$ & + & 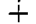 \\
\hline 6 & B. hog cholera . . . . . & - & - & $x$ & - & - & + & - & + & + & + & + & - & - & - & \pm & + & + & $x$ \\
\hline 7 & B. fecalis alcaligenes . . . . & - & - & - & - & + & - & - & - & - & - & - & - & -1 & - & - & - & - & - \\
\hline 8 & B. paratyphosus $\Lambda \ldots \ldots$ & - & - & $x$ & - & - & + & - & + & + & t & $x$ & - & - & - & - & - & + & + \\
\hline 9 & B. paratyphosus A. . . . & - & - & $x$ & - & - & + & - & + & + & $x$ & $x$ & - & - & - & 一 & $x$ & + & $x$ \\
\hline Io & B. paratyphosus B..... & - & - & $x$ & - & \pm & + & - & + & $\dot{x}$ & + & + & - & - & - & - & $x$ & + & + \\
\hline II & B. dysenterica (Flexner). . & + & + & $x$ & - & - & - & - & $\dot{x}$ & $x$ & $x$ & $x$ & $x$ & $\times$ & $\times$ & - & $x$ & $x$ & 0 \\
\hline I 2 & B. typhosus, Strain A. . . & - & - & $x$ & - & - & + & - & $x$ & $x$ & $x$ & $x$ & - & - & $x$ & - & $x$ & $x$ & $x$ \\
\hline$r_{3}$ & B. typhosus, Strain B... & - & - & $x$ & - & - & + & $x$ & $x$ & $x$ & $x$ & $x$ & - & - & $x$ & - & $\times$ & $x$ & $x$ \\
\hline
\end{tabular}

+ Acid and gas (sugars), acid and clot (milk).

$\times$ Acid without gas (sugars), or acid without clot (milk).

\pm Doubtful.

produced we are unable at present to say, unless the changes are due to the formation of different acids or of one acid in excess with the different sugars. The results of these tests are given in Table 2. Cultures were incubated 48 hours at $37^{\circ} \mathrm{C}$. and the results recorded are those occurring in this time and not after a more prolonged period of incubation.

By comparing acid production in litmus and neutral red broth in Tables 8 and 9 it will be noted that different results occurred, especially with the three sugars: levulose, maltose, and lactose. In both sets of experiments the results recorded are those occurring after 48 hours' incubation. These differences may be tabulated as in Table 3 . 
Whether or not these differences are due to the different action of the acids produced upon the indicator or to the question of time of incubation, etc., is being investigated with the larger number of cultures.

TABLE 2 .

Acid Production in Neutral Red Broth.

\begin{tabular}{|c|c|c|c|c|c|c|c|c|c|c|c|c|c|}
\hline \multirow[b]{2}{*}{ No. } & \multirow[b]{2}{*}{ ORGANISM } & \multicolumn{12}{|c|}{ Neutral Red Broth } \\
\hline & & 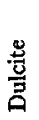 & 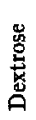 & 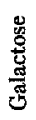 & $\frac{\stackrel{8}{8}}{3}$ & 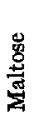 & 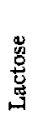 & 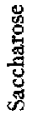 & 峞 & $\underset{\xi}{\stackrel{\xi}{g}}$ & $\begin{array}{l}\stackrel{5}{\mathbf{Z}} \\
\stackrel{4}{\mathrm{~g}}\end{array}$ & 总总 & 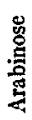 \\
\hline I & B. coli communior . . . . . . . . . . & + & + & + & - & $x$ & - & $\mathrm{x}$ & $x$ & - & $x$ & + & $x$ \\
\hline$\frac{1}{2}$ & B. coli communis . . . . . & $\stackrel{1}{-}$ & + & + & - & $\widehat{x}$ & + & $\hat{+}$ & $\widehat{x}$ & - & $\hat{x}$ & $\vec{x}$ & $\hat{x}$ \\
\hline 3 & B. lactis aërogenes . . . . . . . . . & \pm & + & + & $x$ & $x$ & $x$ & + & $x$ & - & - & $x$ & \\
\hline 4 & B. enteritidis. $\ldots \ldots \ldots \ldots \ldots \ldots$ & + & + & + & - & - & - & - & \pm & - & - & t & - \\
\hline 5 & B. paracoli. . . . . . . . & + & + & + & - & - & - & - & $x$ & - & + & + & \\
\hline 6 & B. hog cholera ....... & - & + & + & - & - & - & - & \pm & - & + & + & + \\
\hline 7 & B. fecalis alcaligenes. . . . . . . . & - & - & - & - & - & - & - & - & - & - & $x$ & $\dot{x}$ \\
\hline 8 & B. paratyphosus $A \ldots \ldots \ldots \ldots \ldots$ & - & + & + & - & - & \pm & - & - & - & + & + & \\
\hline 9 & B. paratyphosus A. . & - & + & + & - & - & - & - & - & - & $\neq$ & + & + \\
\hline Ió & B. paratyphosus B...... & - & + & + & - & - & $t$ & - & - & - & - & $\dot{x}$ & + \\
\hline II & B. dysenterica (Flexner)... & - & + & + & - & - & + & - & + & - & - & - & + \\
\hline 12 & B. typhosus, Strain A... & - & - & \pm & - & - & + & - & - & - & - & + & + \\
\hline $\mathbf{r}_{3}$ & B. typhosus, Strain B . . . . . & - & - & \pm & - & - & + & - & - & - & - & + & + \\
\hline
\end{tabular}

+ Reduction (acid) with purplish color.

$X$ Reduction (acid) with yellow color.

\pm Doubtful.

TABLE 3

Differences in Acm Production hetween Litmus Broth and Neutrai Red Broth.

\begin{tabular}{|c|c|c|c|c|c|c|c|}
\hline \multirow[t]{2}{*}{ No. } & \multirow[t]{2}{*}{ Organism } & \multicolumn{3}{|c|}{ LITMUS Broth } & \multicolumn{3}{|c|}{ Neutral, Red Broth } \\
\hline & & Levulose & Maltose & Lactose & Levulose & Maltose & Lactose \\
\hline $\mathbf{I}$ & B. coli communior... . . . . & + & + & + & - & $t$ & - \\
\hline 2 & B. coli communis ......... & + & + & + & - & + & + \\
\hline 3 & B. aërogenes . . . . . . . . & + & + & + & + & + & + \\
\hline 4 & B. enteritidis $\ldots \ldots \ldots \ldots$ & + & + & - & - & - & - \\
\hline $\mathbf{5}$ & B. paracoli. . . . . . . . & + & + & + & - & - & - \\
\hline 6 & B. hog cholera. & $-f$. & + & - & - & - & - \\
\hline 7 & B. alcaligenes . . . . . . . & - & - & - & - & - & - \\
\hline 8 & B. paratyphosus A..... & + & + & - & - & - & \pm \\
\hline 9 & B. paratyphosus A.... & + & + & - & - & - & - \\
\hline 10 & B. paratyphosus B. . . . . & + & + & - & - & - & + \\
\hline I I & B. dysenterica (Flexner)... & + & + & + & - & - & + \\
\hline 12 & B. typhosus . . . . . . . . & $-t$ & + & + & - & - & + \\
\hline I3 & B. typhosus . . . . . . . & + & + & + & - & - & + \\
\hline
\end{tabular}

2. Immune sera.-These were prepared by giving a series of rabbits intravenous injections of increasing doses of pure cultures of bacilli suspended in salt solution and heated to $58^{\circ} \mathrm{C}$. for one hour, until a full set of highly agglutinative sera were secured.

The sera of a number of typhoid fever convalescents were also 
used in a brief study concerning the practical application of complement-fixation reactions to the diagnosis of infection with a member of the group.

\section{AGGLUTINATION REACTIONS.}

The value of agglutination reactions in differentiating among the members of this group of bacilli is too well known for further comment. Our object was to compare the specificity of the agglutinins and the amboceptors by a series of cross-agglutination experiments. Thus the immune serum of one member of the group is tested against all cultures to determine its agglutinin content for the allied bacilli as a means for studying their relationship and for comparison with the complement-fixation reactions.

Method.-The macroscopic technic was employed. Cultures were grown in neutral broth, filtered and used in doses of $\mathrm{r}$ c.c. The serum dilutions were made up to I c.c., the final total volume in each tube being 2 c.c. Tubes were incubated two hours and placed in the refrigerator over night, readings being made next day. Culture controls as usual.

I. Native agglutinins in normal rabbit serum.-As is generally recognized agglutinins for various members of the typhoid-colon group of bacilli may be demonstrated in normal rabbit serum in low dilutions. As a control on our immune sera, we tested normal rabbit serum with all cultures using dilutions from $I: 100$, to I : 2, $\infty$. As expected, these dilutions were too high for the normal agglutinins of this group except for the following three cultures:

\footnotetext{
B. paratyphosus $A .1: 400$

B. paratyphosus A. $1: 200$

B. coli, Strain A. I : roo
}

2. Titration of immune agglutinins.--Each serum was then titrated with its own organism for ascertaining the exact agglutinin content. The results are given in Table 4.

3. Cross-agglutination experiments.-(a) For the purpose of comparing the specificity of the agglutinins and amboceptors and determining if any relation existed between the two in differentiating among members of the group, the immune sera of four cultures from the three subgroups were titrated against all cultures 
of the general group. In Table 5 are given the results of such titration using the immune serum of $B$. coli communior with all cultures of the group.

TABLE 4 .

Titration of Immune Aggutinins.

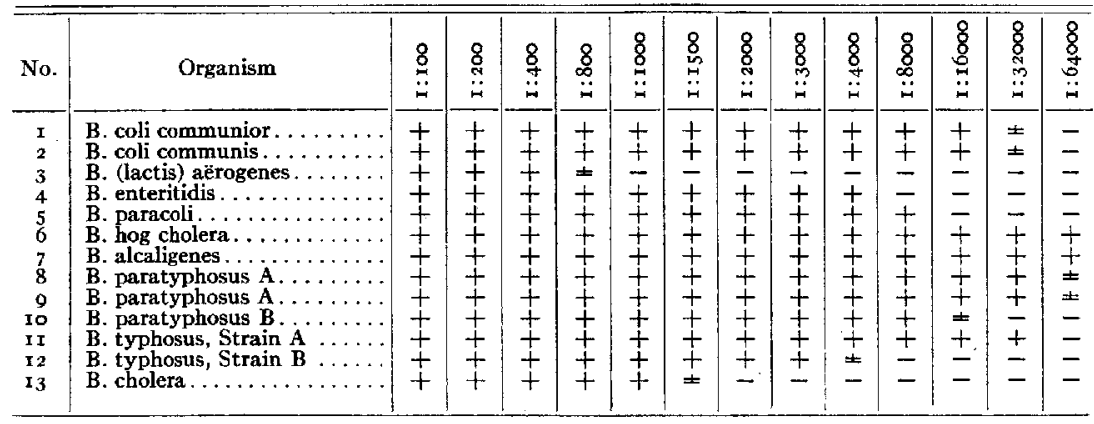

TABLE 5 .

Cross-Agglutination with Immune Serum of $B$. coli communior.

\begin{tabular}{|c|c|c|c|c|c|c|c|c|c|c|c|c|c|c|}
\hline No. & Organism & $\begin{array}{l}8 \\
\stackrel{8}{-} \\
-\end{array}$ & $\underset{i}{\stackrel{8}{8}}$ & 栾 & \begin{tabular}{l}
$\stackrel{8}{8}$ \\
$:$ \\
\hdashline
\end{tabular} & 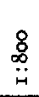 & $\begin{array}{l}\stackrel{8}{8} \\
\stackrel{8}{-} \\
\ddot{\sim}\end{array}$ & 总 & $\begin{array}{l}\text { \&్ } \\
\text { ي } \\
-1 \\
\end{array}$ & \begin{tabular}{l}
8 \\
8 \\
\multirow{2}{*}{} \\
$i$
\end{tabular} & \begin{tabular}{l}
8 \\
8 \\
\hdashline \\
\hdashline
\end{tabular} & 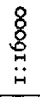 & 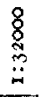 & $\begin{array}{l}8 \\
\frac{8}{8} \\
\stackrel{8}{0} \\
\dddot{H}\end{array}$ \\
\hline I & B. coli communior & + & + & + & + & + & + & + & + & $t$ & + & + & + & - \\
\hline 2 & & + & + & + & & $\div$ & - & & & & & & - & - \\
\hline 3 & B. $(\mathrm{l}$ & + & + & + & + & + & + & - & - & - & - & - & - & - \\
\hline 4 & B. ente & - & - & - & - & - & - & - & - & - & - & - & - & - \\
\hline 5 & B. p: & + & + & + & + & + & - & - & - & - & - & - & - & - \\
\hline 6 & & - & - & - & 二 & - & - & - & - & - & - & - & - & - \\
\hline & B. al & - & - & - & - & - & - & - & - & & - & 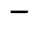 & - & 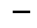 \\
\hline & & - & - & - & - & - & - & - & - & - & - & - & - & \\
\hline 9 & B. para & - & - & $=$ & - & - & $=$ & 二 & $=$ & $\bar{z}$ r r +2 - & $\bar{z}+(x+2+a$ & $\bar{z}+x+a+1$ & - & 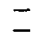 \\
\hline 10 & B. para & $\mp$ & \pm & 二 & Z & - & - & - & $\bar{z}$ & - & $\bar{z}$ & $\overline{-}$ & $\bar{z}$ & - \\
\hline 11 & & $\underline{I}$ & $z$ & $\overline{-}$ & - & & - & 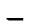 & - & - & - & - & $\overrightarrow{-}$ & - \\
\hline $\begin{array}{l}12 \\
13\end{array}$ & $\begin{array}{l}\text { B. typhosus, Strain B.... } \\
\text { B. cholera.............. }\end{array}$ & $=$ & 二 & $\overline{-}$ & - & $=$ & $\overline{-}$ & - & $=$ & $=$ & $\bar{z}$ & $=$ & - & $\overline{-}$ \\
\hline & & & & & & & & & & & & & & \\
\hline
\end{tabular}

It will be noted that the agglutinin for the particular strain of $B$. coli was quite specific for that strain. Also that this agglutinin gave best reactions with the members of the coli group and was generally negative for the remaining members of the general group except $B$. paracoli and $B$. typhosus, Strain A.

(b) The immune sera of two members of the "enteritidis group" (B. enteritidis and $B$. paratyphosus A) were titrated with all cultures with the results given in Tables 6 and 7 :

It will be noted that in a general way these immune sera gave reactions best with members of their own (enteritidis) group and 


\section{J. A. Kolmer, W. W. Williams, and A. M. Raiziss}

then with the typhoid group, showing practically no agglutination of the coli group in the dilutions employed. The specific relationship between the agglutinin and its homologous culture $(\mathrm{r}: 6400)$ is to be noted with $B$. paratyphosus $\mathrm{A}$ having agglutinated a closely allied culture, $B$. paratyphosus $\mathbf{B}$, only in comparatively low dilution ( $1: 1500)$.

TABLE 6.

Cross-Agglutination with Immune Serum of B. enteritidis.

\begin{tabular}{|c|c|c|c|c|c|c|c|c|c|c|}
\hline No. & Organism & $I: 100$ & $I: 200$ & I : 400 & $1: 600$ & $1: 800$ & I: $: 1000$ & $1: 2000$ & I: 4000 & $x: 8000$ \\
\hline $\mathbf{r}$ & B. coli communior & - & - & - & - & - & - & - & - & - \\
\hline 2 & B. coli communis. & + & - & - & - & - & - & - & - & - \\
\hline 3 & B. aërogenes.... & - & - & - & - & - & - & - & - & - \\
\hline 4 & B. enteritidis. & + & + & + & + & + & + & + & + & - \\
\hline 5 & B. paracoli... & + & - & - & - & - & - & - & - & - \\
\hline 6 & B. hog cholera. & $\dot{t}$ & \pm & - & - & - & - & - & - & - \\
\hline 7 & B. alcaligenes.... & - & - & - & - & - & - & - & - & - \\
\hline 8 & B. paratyphosus A & + & + & + & \pm & - & - & - & - & - \\
\hline I0 & B. paratyphosus B & + & \pm & - & - & - & - & - & - & - \\
\hline I 2 & B. typhosus...... & + & \pm & - & - & - & - & - & - & - \\
\hline$x_{3}$ & B. typhosus. & + & + & + & - & - & - & - & - & - \\
\hline 14 & B. cholera & - & - & - & - & - & - & - & - & - \\
\hline
\end{tabular}

TABLE 7.

Cross-Aggutination with Imanue Serum of B. paratyphosus A

\begin{tabular}{|c|c|c|c|c|c|c|c|c|c|c|}
\hline No. & Organism & $I: 100$ & $x: 200$ & $x: 400$ & $x: 600$ & $1: 800$ & $1: 1000$ & $x: 1500$ & $\mathrm{I}: 2000$ & $1: 4000$ \\
\hline $\mathbf{I}$ & B. coli communior & - & - & - & - & - & - & - & - & - \\
\hline 2 & B. coli communis. & - & - & - & - & - & - & - & - & - \\
\hline 3 & B. aërogenes.... & - & - & - & - & - & - & - & - & - \\
\hline 4 & B. enteritidis. & + & + & \pm & - & - & - & - & - & - \\
\hline 5 & B. paracoli.... & + & + & - & - & - & - & - & - & - \\
\hline 6 & B. hog cholera. ... & - & - & - & - & - & - & - & - & - \\
\hline 7 & $\vec{B}$. alcaligenes. . . & - & - & - & - & - & - & - & - & - \\
\hline 8 & B. paratyphosus A & + & + & + & + & + & + & + & + & + \\
\hline to & B. paratyphosus B & + & + & + & + & + & + & \pm & - & - \\
\hline I 2 & B. typhosus. . . . & + & + & \pm & - & - & - & - & - & - \\
\hline 13 & B. typhosus. & + & + & - & - & - & - & - & - & - \\
\hline I4 & B. cholera. . & - & - & - & - & - & - & - & - & - \\
\hline
\end{tabular}

(c) The immune serum of one member of the "typhoid group" (B. typhosus, Strain A) was titrated with all cultures as given in Table 8.

It will be noted in general that the agglutinin of this serum was no more potent for its own culture than for another strain of B.typhosus, that it agglutinated to some degree all members of the "enteritidis group" but caused no agglutination whatsoever of members of the "coli group."

(d) Summary of agglutination experiments.-(I) No native agglutinins for members of the typhoid-colon group of bacilli were 
found in normal rabbit serum in dilution of $\mathrm{I}: \mathrm{ro0}$ and higher except for $B$. paratyphosus $A$ and $B$. coli communior

(2) Selecting the immune serum of $B$. coli communior as a representative of the "colon group" and titrating it with all cultures used in the study it was found that agglutination was best marked with the homologous culture. This serum also agglutinated the other members of the group, $B$. coli communis and B. lactis aèrogenes in lower dilutions; it did not, however, agglutinate the members of the "enteritidis" and typhoid group except in two instances, $B$. paracoli $(\mathrm{r}: 800)$ and $B$. typhosus, Strain $\mathrm{A}(\mathrm{I}: \mathrm{r}, 0)$.

TABLE 8.

Cross-Agglutination with Imadune Serum of B. typhosus, Strain A.

\begin{tabular}{|c|c|c|c|c|c|c|c|c|c|c|c|c|c|c|}
\hline No. & Organism & $\underset{H}{8}$ & \begin{tabular}{l}
8 \\
\hdashline \\
-1
\end{tabular} & $\frac{8}{7}$ & $\underset{ت}{\stackrel{8}{\circ}}$ & \begin{tabular}{l}
8 \\
0 \\
\hdashline \\
-4
\end{tabular} & \begin{tabular}{l}
8 \\
8 \\
9 \\
\hdashline
\end{tabular} & 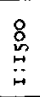 & \begin{tabular}{l}
8 \\
8 \\
-4 \\
\hdashline-7
\end{tabular} & \begin{tabular}{l}
8 \\
8 \\
$\vdots$ \\
\hdashline \\
-1
\end{tabular} & 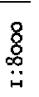 & \begin{tabular}{l}
8 \\
8 \\
$\stackrel{8}{*}$ \\
\hdashline
\end{tabular} & $\begin{array}{l}8 \\
\underset{-}{8} \\
:\end{array}$ & \\
\hline $\begin{array}{r}\mathbf{F} \\
2 \\
3 \\
4 \\
5 \\
6 \\
7 \\
8 \\
9 \\
9 \\
10 \\
12 \\
13 \\
14\end{array}$ & 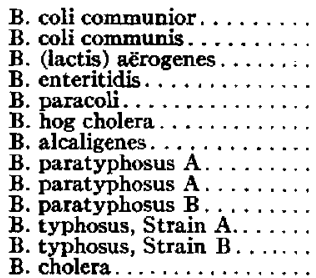 & $\begin{array}{l} \pm \\
\overline{+} \\
+ \\
+ \\
+ \\
+ \\
+ \\
+\end{array}$ & $\begin{array}{l} \pm \\
\pm \\
+ \\
+ \\
+ \\
+ \\
+ \\
+ \\
+\end{array}$ & $\begin{array}{l}- \\
\pm \\
\overline{+} \\
+ \\
\pm \\
+ \\
+ \\
+ \\
+\end{array}$ & 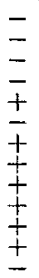 & $\begin{array}{l} \pm \\
\pm \\
\pm \\
\pm \\
\pm \\
+ \\
+ \\
+ \\
+\end{array}$ & $\begin{array}{l}z \\
= \\
= \\
= \\
\pm \\
\pm \\
\pm \\
\pm \\
\pm\end{array}$ & $\begin{array}{l}\overline{-} \\
\bar{z} \\
\bar{z} \\
\bar{t} \\
\pm \\
\pm \\
\pm\end{array}$ & $\begin{array}{l}= \\
= \\
= \\
= \\
= \\
\pm \\
\pm \\
\pm \\
\pm\end{array}$ & $\begin{array}{l}\bar{z} \\
\bar{z} \\
\bar{z} \\
\overline{ \pm} \\
\overline{ \pm} \\
\pm\end{array}$ & $\begin{array}{l}\bar{z} \\
\bar{z} \\
\bar{z} \\
\bar{z} \\
\bar{z} \\
\pm \\
\pm\end{array}$ & $\begin{array}{l}= \\
= \\
= \\
= \\
= \\
= \\
= \\
\pm \\
\pm\end{array}$ & 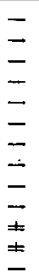 & $\begin{array}{l}\bar{z} \\
= \\
\bar{z} \\
\bar{z} \\
\bar{z} \\
\bar{z} \\
\bar{z}\end{array}$ \\
\hline
\end{tabular}

(3) Using the immune sera of B. enteritidis and B.paratyphosus A as representatives of the "enteritidis group" it will be noted in general that the cross-agglutination tests demonstrated the close relationship of this group to the "typhoid" rather than to the "coli" group. There is apparently a closer interrelationship among $B$. enteritidis, B. paracoli, B. paratyphosus $\mathrm{A}$ and $\mathrm{B}$, and $B$. typhosus than with any other members of the typhoid-colon group.

(4) Titrating the immune serum of a strain of B.typhosus with all cultures it was found that agglutination with the homologous culture did not exceed that resulting with another strain of $B . i y$ phosus and demonstrated by means of agglutination of members of the "enteritidis" group the close interrelationship of the "typhoid" with the "enteritidis group." The negative results 


\section{J. A. Kolmer, W. W. Williams, and A. M. Raiziss}

with the "coli" group would indicate that the colon and typhoid bacilli are entirely separate entities or that the relationship is very distant. These results are substantiated by the complementfixation reactions.

\section{COMPLEMENT-FIXATION EXPERIMENTS.}

Of serological reactions, that of complement-fixation should be most accurate and specific as indicating the presence of immune amboceptor, the result of cellular changes incident to the introduction of bacterial or any other protein antigenic substances. As is well known, the agglutinins produced by members of the typhoidcolon group are more or less specific in the higher dilutions, yielding in most instances a group reaction in lower dilutions. The object of these experiments was to test the specificity of the amboceptors as compared to the agglutinins and to indicate in this manner the biological relationship of the members to each other.

Method.-Briefly this consisted in testing each culture antigen with all immune sera. The best reactions would likely occur between homologous antigen and immune serum, and the subsidiary reactions occur if amboceptor for the antigen in question were present in the other immune sera. To study the specificity of the amboceptors two methods were employed: (a) using a constant dose of antigen and increasing doses of immune sera and $(b)$ using a constant amount of immune serum with increasing or decreasing doses of antigen.

(I) Antigens.- The preparation of the antigens in experiments of this nature is an important feature. The specific antigenic principle may be in the nature of an endotoxin and apart from the general protein structure of the bacterial cell. The method of Besredka as modified by Gay has this possibility in view in the preparation of bacterial antigens. On the other hand the organism may secrete a substance diffusible in the culture media which may represent the more specific antigenic principle. Both methods were used in this study, the latter being chosen for most of the work because much more readily prepared and yielding apparently the same results as secured by the Besredka method.

Method No. I.-Cultures were grown in neutral broth for 48 
hours and filtered to remove clumps of organisms. The filtrate was then heated to $60^{\circ} \mathrm{C}$. for an hour. One per cent phenol and glycerin were added as preservatives. Antigens were then titrated for antigenic and anticomplementary doses. These antigens are very simple in preparation and keep for long periods of time in the ice-chest.

Method No. 2 (Besredka-Gay).-Cultures were grown on slanted neutral agar for 48 hours. The growths were washed off with small amounts of sterile salt solution. The saline suspensions were precipitated with an equal quantity of absolute alcohol and centrifugalized. The sediment was then dried over calcium chlorid, accurately weighed, ground into a fine powder and made up into a 2 per cent suspension in 0.85 per cent salt solution. This suspension was diluted with sterile salt solution to $I / 40, I / 80$, $\mathrm{I} / \mathrm{I} 60, \mathrm{I} / 320, \mathrm{I} / 640$, and I/I 280 and I c.c. of these dilutions used in each tube of the experiment as shown in the tables. The actual amounts of dry antigenic substance contained in I c.c. as used were as follows:

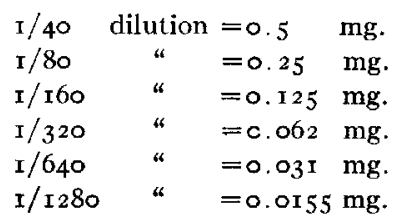

In using an antigen so prepared each dose was controlled to guard against anticomplementary effects. Several antigens were used in larger doses but so many were anticomplementary that we were forced to use the higher dilutions given above.

With antigens made according to the first technic two methods may be used in conducting complement-fixation reactions: (a) Ascertaining the anticomplementary dose and adopting an arbitrary amount which is less than the anticomplementary dose or $(b)$ titrating the exact antigenic dose of the antigen with its immune serum. This dose is selected as that giving complete inhibition of hemolysis and must be several times less than the anticomplementary dose. As will be seen in the accompanying table of these titrations, this method of preparing antigens yielded good results, i.e., the anticomplementary was from to to 20 times greater than the antigenic 

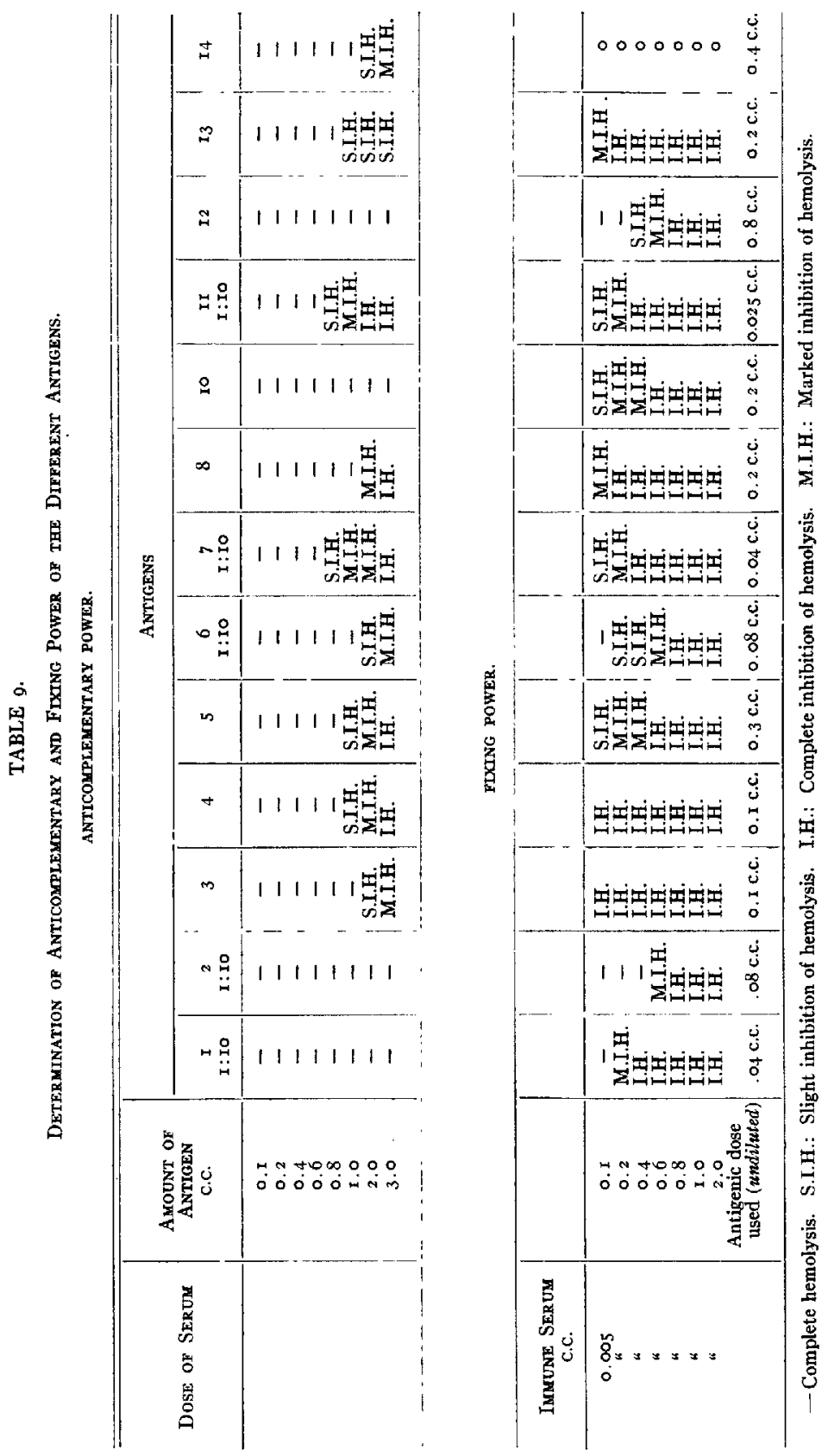
dose. It appeared to us that since we were searching for the most delicate reactions between an antigen and any possible amboceptor for this antigen which may be present in other immune sera, it would be better technic to use the antigenic dose and vary the quantity of immune serum.

(2) Immune sera.-These were inactivated by heating to $55^{\circ} \mathrm{C}$. for half an hour. In titrating the antigenic doses of the various antigens, 0.005 c.c. of the homologous immune serum was used in each tube (Table 8). In conducting the reactions the titrated antigenic dose of the antigen being tested was employed with increasing doses of the immune sera, as follows: 0.001 c.c., 0.004 c.c., 0.008 c.c., 0.01 c.c., and 0.02 c.c.

(3) Hemolytic system.- Complement was furnished by the fresh sera of guinea-pigs, diluted $\mathrm{I}: 20$ and used in dose of I c.c.; antisheep rabbit amboceptor was titrated before each experiment and used in amounts equal to two hemolytic doses; washed sheep corpuscles were employed in a 2.5 per cent suspension, dose I c.c.

Serum, antigen, and complement were mixed and diluted with $\mathrm{NaCl}$ solution to 3 c.c.; incubated one hour at $37^{\circ} \mathrm{C}$; two hemolytic doses of amboceptor and I c.c. corpuscles added; reincubated for one to two hours, depending upon the hemolysis of the controls; tubes were then placed in refrigerator over night, readings being made the following morning.

(4) Controls.-Controls of each serum in maximum dose used also antigen, complement, corpuscles, and hemolytic controls. A normal serum was used each time with each antigen. In the doses of sera used by us we did not note the presence of native amboceptor for any of the antigens except in one instance: $B$. paracoli which yielded a weak reaction with the maximum dose of serum (Table I4).

The following tables show the results. As already stated the numbers are the same for each immune serum and its antigen, thus, No. I refers to culture No. I (B. coli communior), and its immune serum (No. I), etc.

A study of Tables ro-22 shows the following:

r. The immune amboceptor for $B$. coli is highly specific with its own antigen. While the two strains used were slightly different in their fermentative powers with the various sugars, they may be 

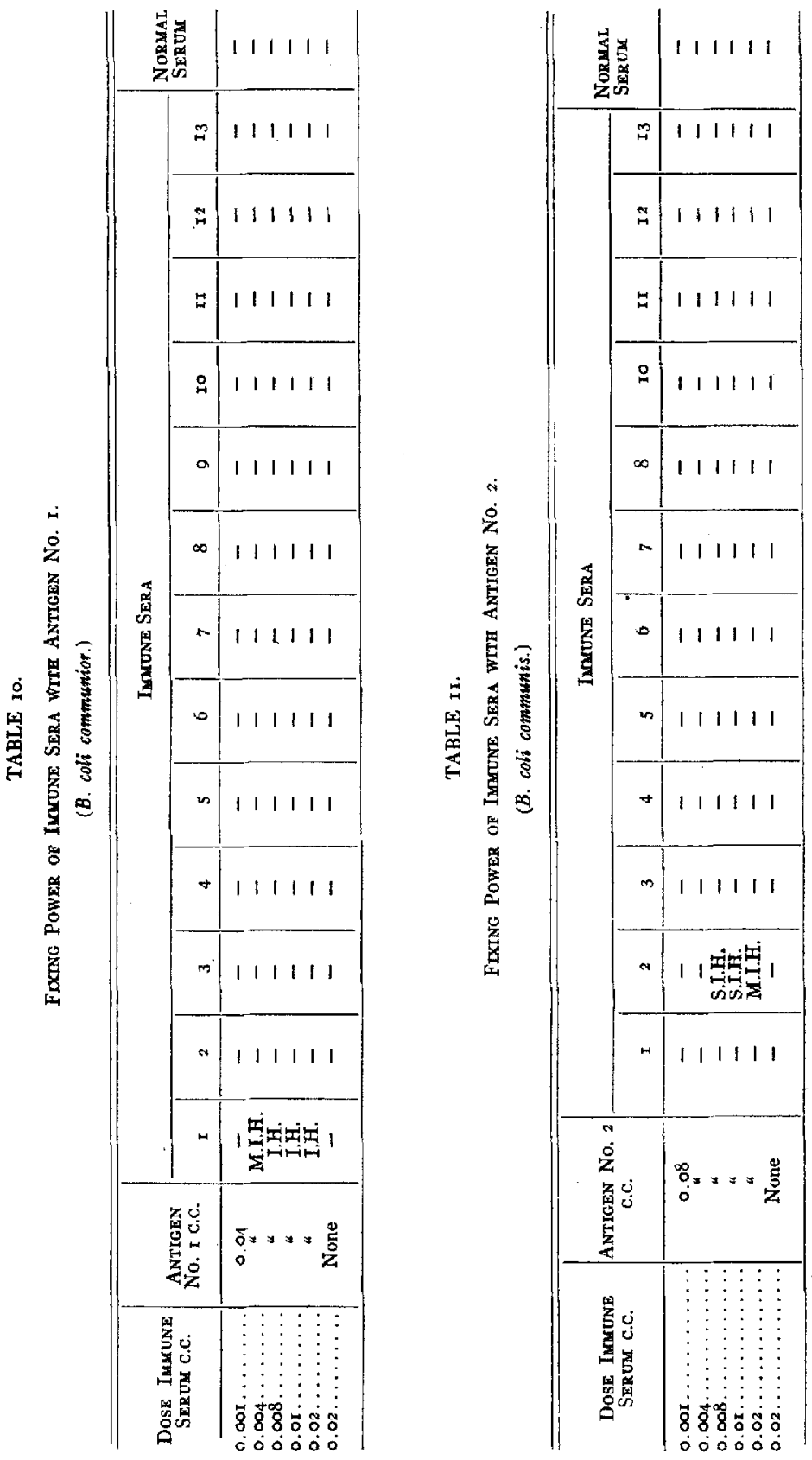
Typhom Colon Group of Bacilli
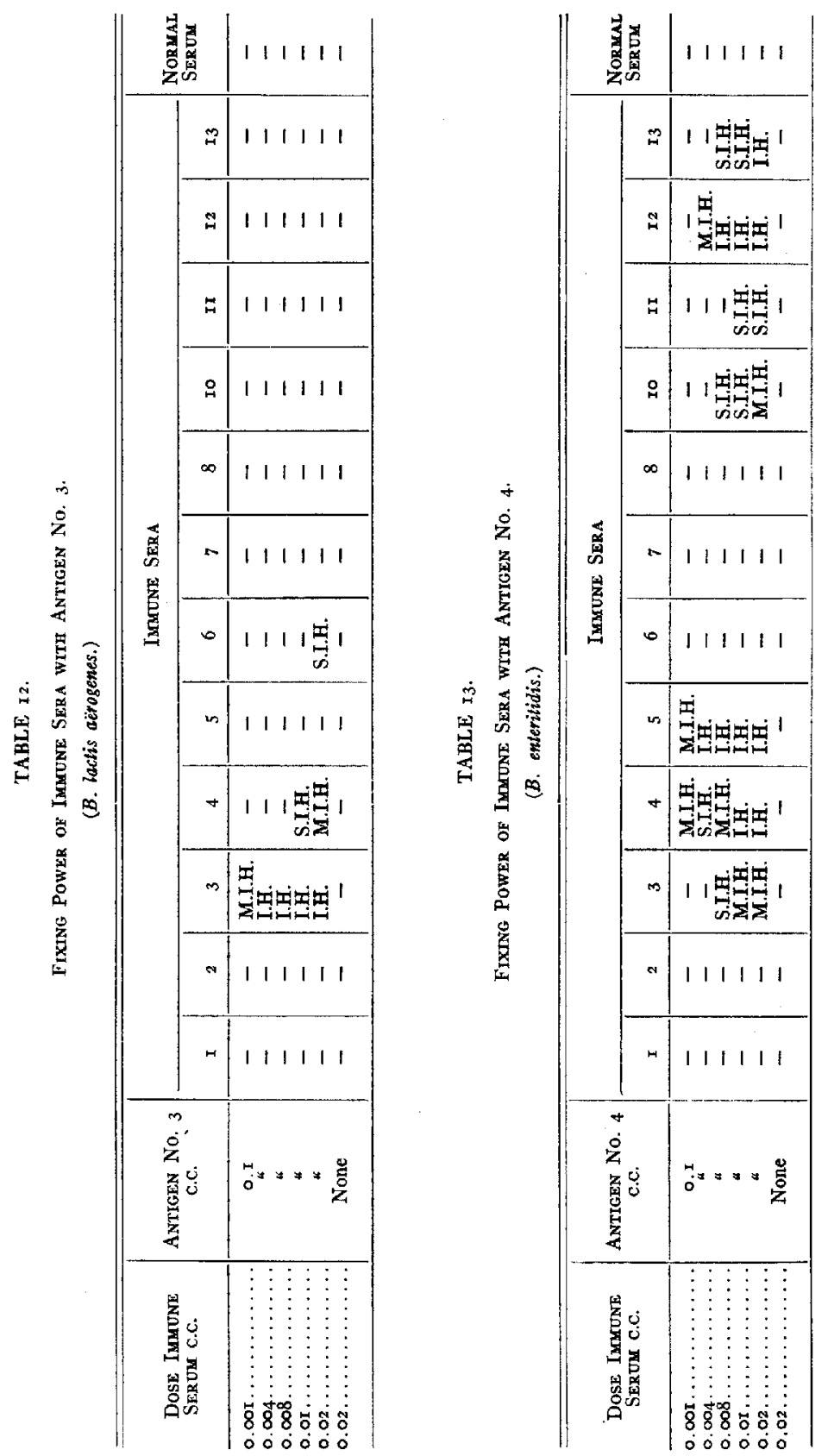
338 J. A. Kolmer, W. W. Williams, and A. M. Raiziss
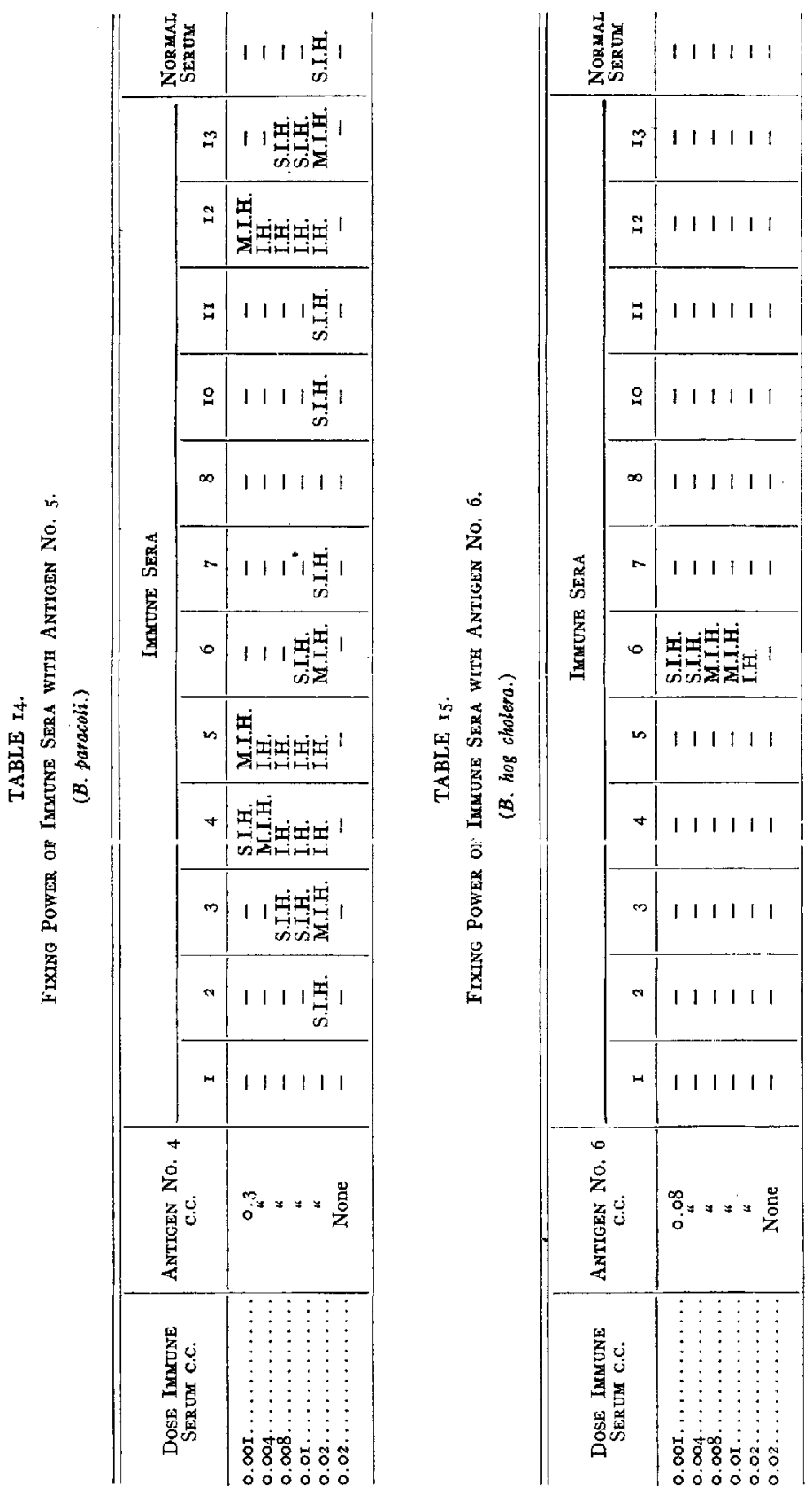

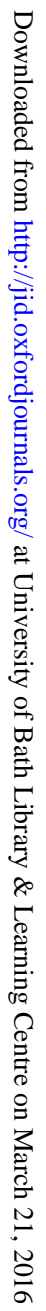



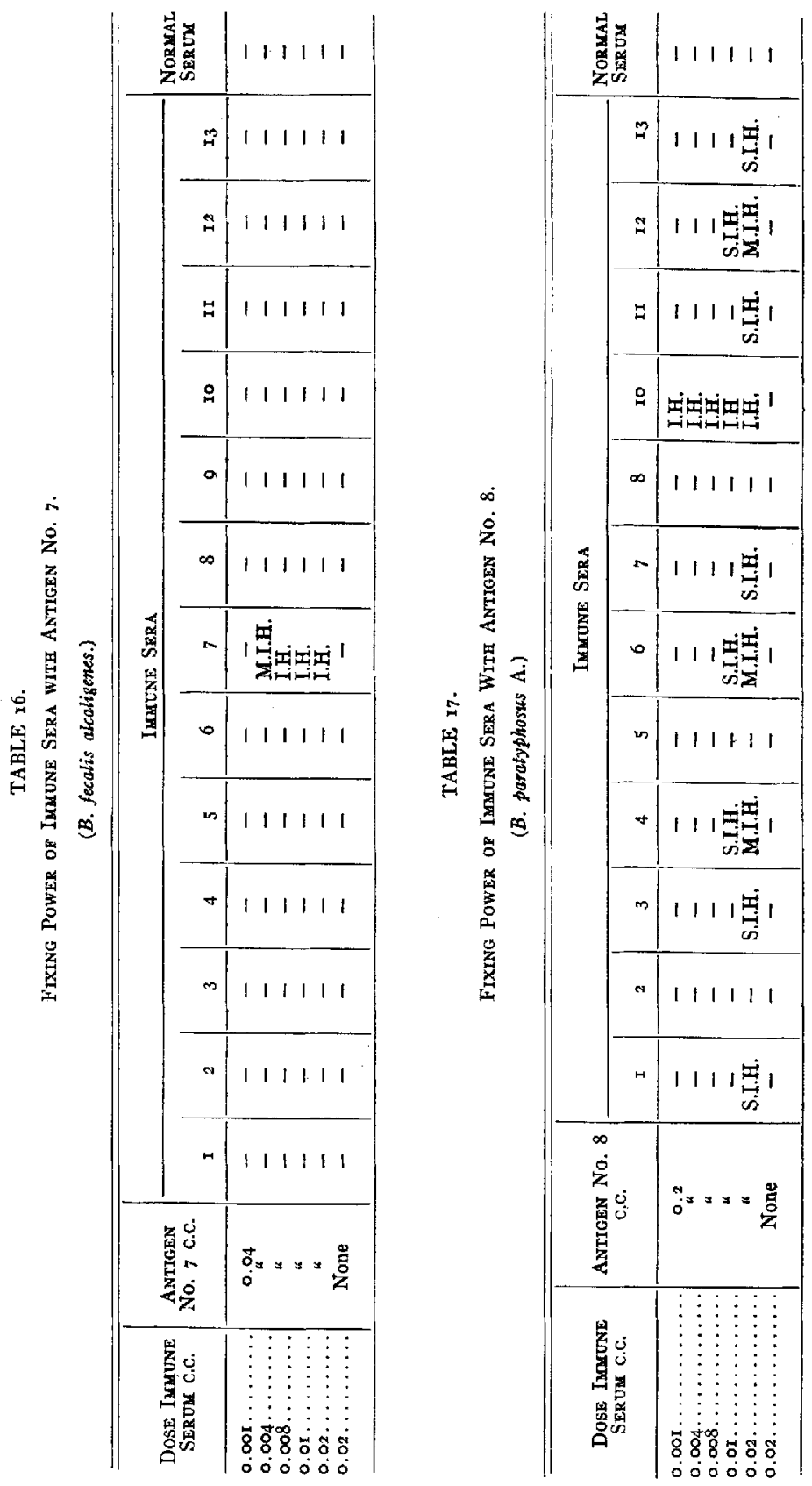

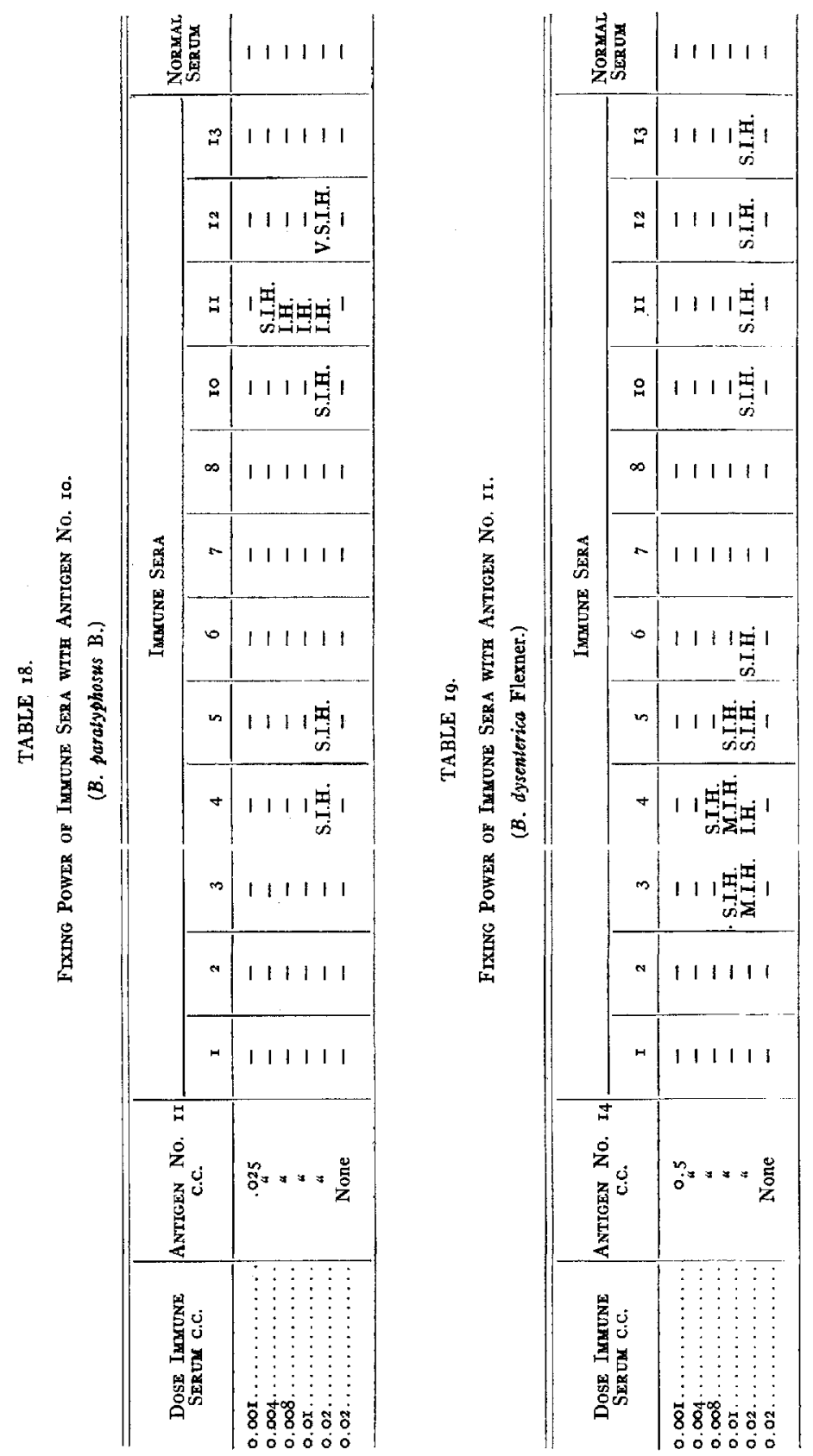


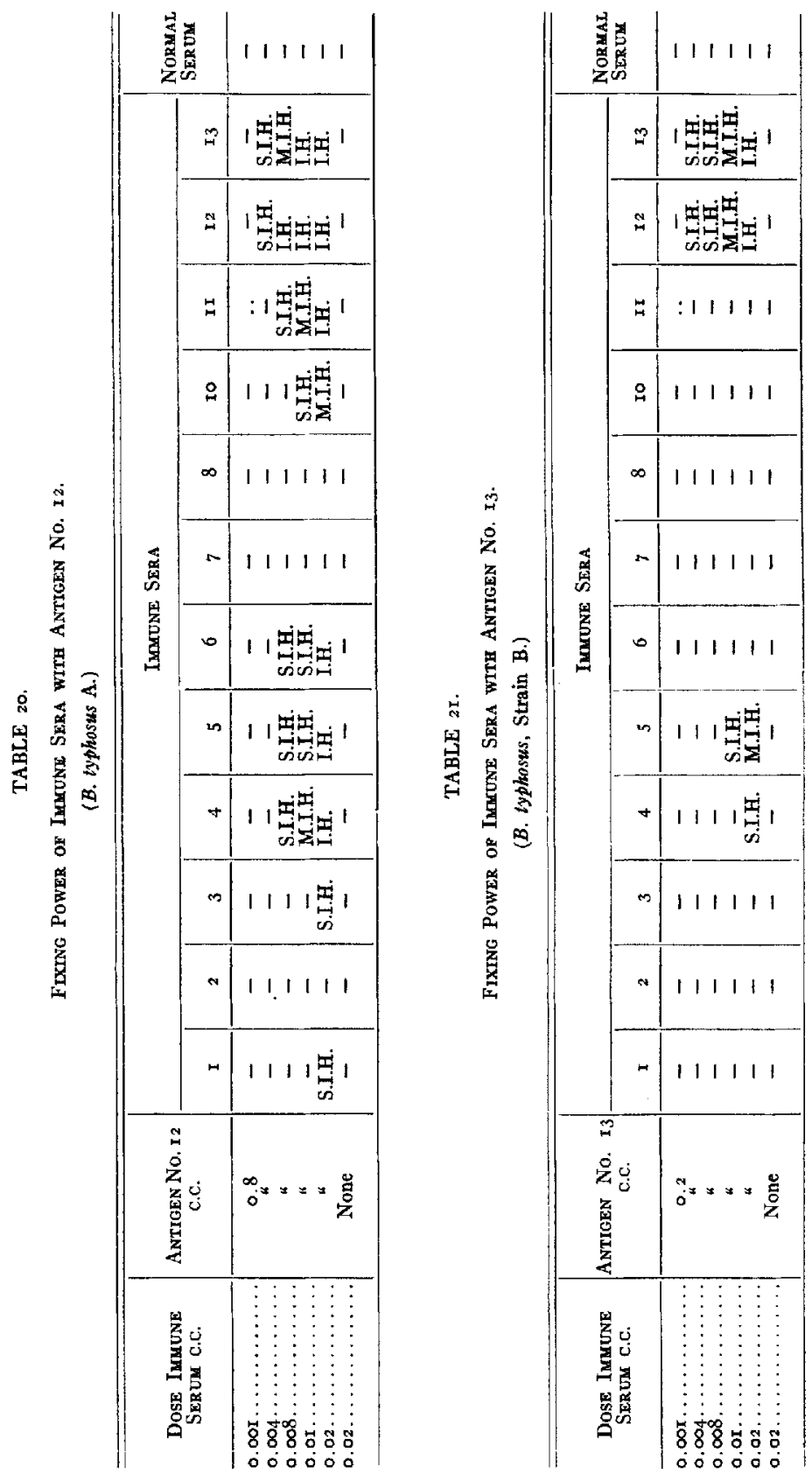


342 J. A. Kolmer, W. W. Williams, and A. M. Raiziss

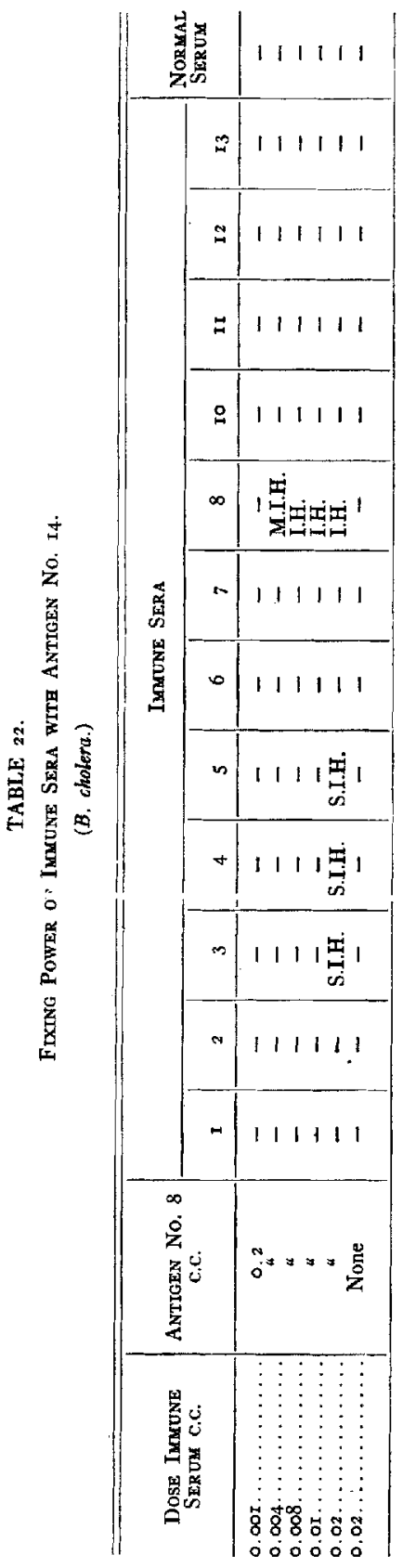

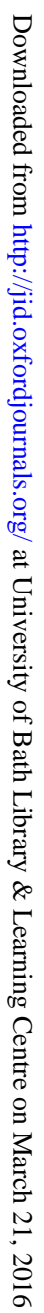


regarded as closely allied organisms, altho it will be noted in Tables Io and I I that their amboceptors reacted only with the homologous antigen. The specificity of the agglutinins is not as marked as with the amboceptors because some agglutination occurred with other members of the group in crossing with the immune serum of $B$. coli communior: for example, $B$. coli communis, $B$. aërogenes, and $B$. paracoli. It is to be noted throughout the study that the coli immune sera did not in general contain amboceptor for other members of the group.

2. The antigen of $B$. lactis aërogenes reacted best with its homologous immune serum and to a lesser extent with the immune sera of $B$. enteritidis and B. hog cholera. While this bacillus is classed with the coli group the complement-fixation reactions would indicate a clear relationship to the above organisms.

3. The antigen of $B$. enteritidis reacted best with its own immune serum and that of $B$. paracoli and to a lesser extent with the sera of $B$. typhosus, $B$. paratyphosus $\mathrm{A}$, and $B$. aerrogenes. The immune serum of this bacillus likewise agglutinated the above cultures but there is apparently no relation between the quantities of agglutinins and amboceptors present. The apparent close interrelationship of $B$. enteritidis to $B$. paracoli, $B$. aërogenes, and the paratyphoids will be noted throughout the experiments.

4. The close interrelationship of $B$. paracoli to $B$. enteritidis, $B$.typhosus, and $B$. aerrogenes is indicated by the amboceptors for this organism present in the immune sera of these cultures.

5. The antigens of $\mathbf{B}$. hog cholera and B. alcaligenes reacted only with their immune sera and the absence of amboceptors for these antigens in the immune sera of the other members of the group may be regarded as indicating, serologically at least, their more distant relationship to the members of the colon-typhoid group.

6. The higher specificity of immune amboceptor over agglutinin is apparent by comparing Tables 7 and $x 7$, when it will be noted that the antigen of $B$. paratyphosus A reacted strongly with its own immune serum and to a slight degree with $B$. paratyphosus $B$, $B$. typhosus, $B$. enteritidis, etc. The immune serum of this antigen agglutinated practically the same organisms but the differentiation was less sharply defined. The more specific character of the ambo- 


\section{J. A. Kolmer, W. W. Williams, and A. M. Raiziss}

ceptor is also noted by the well marked reaction between the antigen of $B$. paratyphosus $\mathrm{B}$, and its immune serum, and very slight reactions with the sera of $B$. paratyphosus A, B. lyphosus, $B$. enteritidis, and $B$. paracoli.

7. The antigen of $B$. typhosus (Strain A) reacted as well with the immune serum of Strain B as with its homologous serum. Reactions also occurred with the immune sera of the same cultures as were agglutinated by the serum of Strain A, altho there is apparently no quantitative relationship. The antigen of Strain B reacted more specifically, giving strong complement-fixation with the amboceptor of its own serum and that of Strain $A$, and yielding slighter reactions with the immune serum of $B$. paracoli and $B$. enteritidis.

8. Since several varieties of $B$. dysenterica are usually classified with the typhoid group it was considered of interest to prepare an antigen of at least one well known strain and test for amboceptor in the immune sera of the series. As will be noted in Table 19 best reactions occurred with $B$. enteritidis, B. paracoli, and $B$. aërogenes, very slight reactions resulting with immune sera of $B$. typhosus and the paratyphoids. This would indicate, serologically, the closer relationship of this strain to $B$. enteritidis and B. paracoli.

$\bar{y}$. As a control on the investigation a cuicure of cnoiera was carried along with the series. This organism was selected because it is an inhabitant of the intestinal tract as are the members of the typhoid-colon group altho readily differentiated from these by biological characters and agglutination tests. It will be noted that the cholera immune serum did not show the presence of any amboceptor for the members of the typhoid-colon group altho its antigen yielded very slight reactions with the immune sera of $B$. aërogenes, $B$. enteritidis, and $B$. paracoli.

There was practically no difference in results with the use of antigens prepared according to the method of Besredka as modified by Gay. This method is probably the best we have for the purpose of liberating any specific antigenic substance as an endotoxin which would serve to yield more specific reaction and differentiate among the members of a group of closely allied organisms. The three specimen tables, 23, 24, and 25, compared in order with Tables Io, 18 , and 20 , show that results were practically the same. 

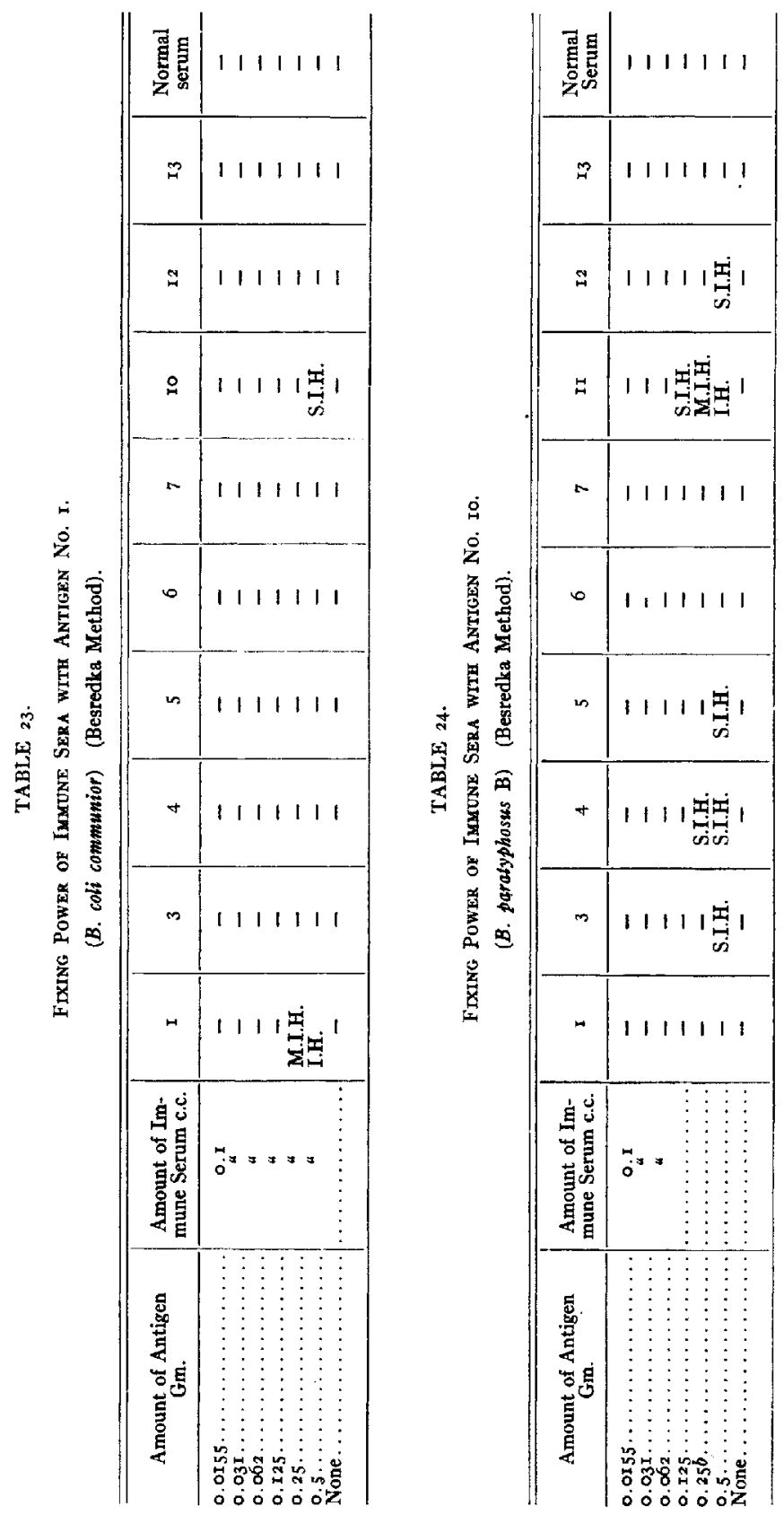
346 J. A. Kolmer, W. W. Williams, and A. M. Raiziss

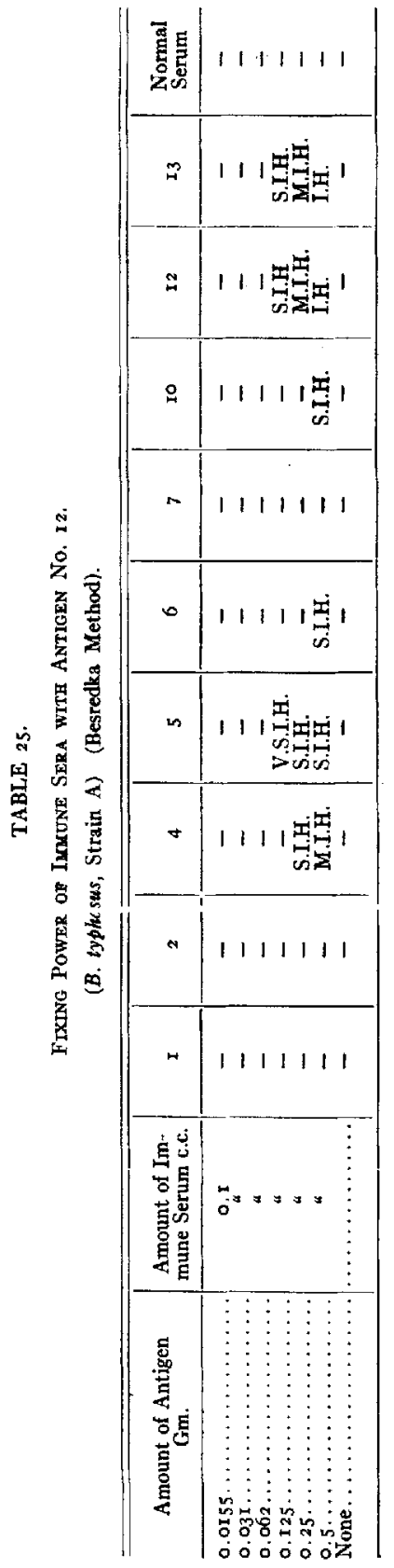

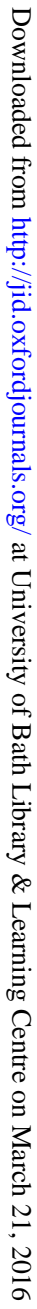


Having the full set of antigens on hand it was considered of interest to try out a number of sera of typhoid-fever patients to ascertain the specificity of complement-fixation experiments as a practical diagnostic procedure in the presence of infection with a member of the typhoid-colon group. In this experiment the antigens were used in one-quarter the anticomplementary dose as representing the simplest practical method. The sera were titrated with a culture of $B$. typhosus (Strain B) for agglutinin content; were then inactivated and used in dose of 0 . I c.c. for the complement-fixation experiment. As usual, serum, antigen, hemolytic, etc., controls were set up. The results are given in Table 26 .

It will be noted ( $\mathrm{I}$ ) that with each serum the strongest reactions occurred with the culture antigens of the two strains of B. typhosus; (2) that according to these results, complement-fixation tests with these antigens are essentially group reactions; (3) that the same interrelationship among B. typhosus, B. paratyphosus, B. enteritidis, and $B$. paracoli, as was noted with the immune rabbit sera, is here shown.

\section{GENERAL CONCLUSIONS.}

I. The absolute differentiation among members of a "group" of organisms by complement-fixation reactions does not seem possible. The organisms belonging to such "groups" possess antigenic principles in common which produce a more general amboceptor and yield essentially a "group" reaction. In differentiating among various "groups," however, complement-fixation reactions are probably the most exact at our command. The work of Craig and Nickols with several cultures of spirochetes including Treponema pallidum, of Claypole with different strains of streptothrices, and the work with the group of streptococci, diphtheria, and typhoid-colon group, all indicate that complement-fixation reactions with bacterial antigens and immune amboceptors are essentially "group" reactions.

2. As between agglutination and complement-fixation reactions in differentiating among the individual species of a certain group of organisms, results would indicate that the amboceptors are more 
348 J. A. Kolmer, W. W. Williams, and A. M. Raiziss

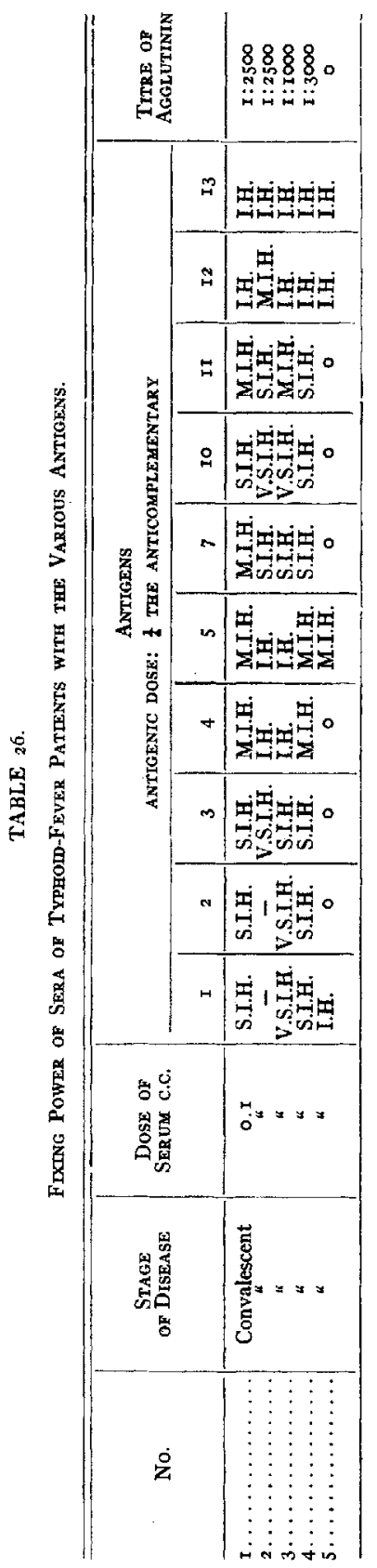

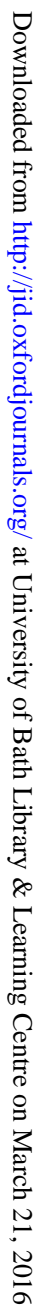


specific than the agglutinins, or in other words, that complementfixation reactions with the proper technic are more delicate than agglutination reactions. As a practical procedure, however, the agglutination reactions are so much simpler that the more complicated and time-consuming fixation technic is not serviceable as a practical routine procedure. 